\title{
EFFECTIVENESS, EFFICIENCY, AND PROMPTNESS OF CLAIMS HANDLING PROCESS IN THE NIGERIAN INSURANCE INDUSTRY
}

\author{
Tajudeen Olalekan Yusuf', Sunday Stephen Ajemunigbohun"
}

\author{
${ }^{1}$ University of Lagos, Lagos, Nigeria \\ 2 Lagos State University, Lagos, Nigeria
}

\section{ABSTRACT}

This study was designed with the aim of investigating the effectiveness, efficiency and promptness of claims handling process within the Nigerian insurance industry. To this end, the researchers have been able to assess the effectiveness and efficiency of claims handling process and thus, examine its promptness in relation to the organizational productivity of insurance companies in Nigeria. The study employed a cross-sectional type of survey design. A judgmental sampling technique was employed and relevant data were gathered through the use of structured questionnaire. The sample population consisted of 107 respondents made up of some members of staff within claims department drawn from 33 insurance companies which were selected from the directory of member companies. The major statistical technique employed for this study was a One Sample T-test. Two hypotheses were tested in this study. The hypotheses tested in the study found that managing claims effectively and efficiently will significantly affect operational process in claims management and thus, promptness in claims handling processes does essentially assist in fraud detection and prevention. The study recommends that claims manager should put forward strategic plans to ensuring that insurance claims complaint files are properly kept, monitored and handled for needs that may warrant its usefulness in the future. Claims handling procedures should be promptly managed to avoid deficiency in organization's operational objectives, and lastly, Government should ammonize their resources and technical know how with the Nigerian insurance industry in ensuring that insurance claims are well designed to curtail fraudulent claims experienced in the past.

\section{JEL CLASSIFICATION \& KEYWORDS}

- U9 CLAIMS HANDLING PROCESS EFFECTIVENESS - EFFICIENCY - PROMPTNESS ․ INSURANCE INDUSTRY - NIGERIA

\section{INTRODUCTION}

Oftentimes, loss situations awake the minds of the insuring public towards their insurer, as many consumers pay little attention to their insurance coverage until they have a loss. Claims, being the heartbeat of insurance, are the most critical contact the insuring public has with the industry and thus, critical moment of truth that shapes a customer's overall perception of their insurer (Crawford, 2007). Singh (2007) noted that claims are the defining moment in the customer relationship for insurance firms, with a firm's success often defined by one factor: the customer's experience around claims.

A claim is a demand made by the insured person to the insurer for the payment of benefits under a policy (Asokere \& Nwankwo, 2010). However, to reduce the cost of claims and deliver on a value-added brand promise to customers, non-life insurers are focusing on enhancing efficiency and

II toyusuf@yahoo.com@yahoo.com

" insurancelecturerlasu2009@yahoo.com

www.journals.cz effectiveness in their claims function. Claims processing is the gateway to the customer that will drive improvement in the insurers' customer acquisition, retention, enterprise business intelligence for product development insights and profitability for the next several years (Capgemini, 2011a). The speed, accuracy and effectiveness of claims processing is also paramount for controlling costs, managing risks and meeting portfolio underwriting expectations (IBM, 2011).

The task of handling claims process has been challenging. However, modernizing the claims process for efficiency, effectiveness and flexibility has been being daunting task, due to the fact that it is a mission-critical function that touches all parts of the organization, affecting competitive positioning, customer service, fraud management, risk exposure, cost control, and IT infrastructure (TIBCO, 2011). However, Singh (2012) points at certain inefficiencies that are driving up claims costs and adversely affecting customers' claims experience. These inefficiencies include: aging technology, increasing process complexity, and a rising number of fraudulent claims. Previous attempts to improve the process have typically been limited to expedite a series of inefficient and disconnected processes or of reducing manual steps.

Efficiency is the ability to minimize the use of resources in achieving organizational objectives (Khan, Khan, Ahmed, \& Ali, 2012). Effectiveness, on the other hand, is said to be the extent to which stated objectives are met- the policy achieves what it intended to achieve (Productive Commission, 2013). Ilona \& Evelina (2013) added that excellent organizational efficiency could improve entities performance in terms of management, productivity, quality and profitability. Zheng, Yang, \& McLean (2010) are of the opinion that effectiveness determines the policy objectives of the organization or the degree to which an organization realizes its own goals.

Claims handling service is being said to be the basis on which an insurance company is ultimately judge by clients and the key issue affecting the reputation of the insurer. However, the payment of legitimate claims represents the delivery of the promise at the heart of the insurance contract; which, indeed, for many insurance companies, excellent claims handling service is considered to be a differentiator that distinguished them from the competition (AIRMIC, 2009). An earlier submission, according to Organization for Economic Co-operation and Development (2014), opined that good practice for insurance claim management involves: claims reporting; receipt of claims by the company; claims files and procedures; fraud detection and prevention; claims assessment; claim processing; timely claim processing, complaints and dispute settlement; and supervision of claims-related services.

The way an insurer handles a claim often determines to a large extent the insured's opinion of and loyalty to the insurer. However, with claims being the largest single cost item for insurers, controlling claims expenses through 


\section{EFFECTIVENESS, EFFICIENCY, AND PROMPTNESS OF CLAIMS HANDLING PROCESS IN THE NIGERIAN INSURANCE INDUSTRY}

a streamlined process can have a dramatically positive bottom-line impact while providing new and unique differentiating flexibility in claims processing, which enables the company to innovate and react quickly to unpredictable events and changes in the competitive landscape (TIBCO, 2011). Different claims managers and administrators within the Nigerian insurance industry had proven that claims procedural processes are being followed and timely responded to. Previous studies such as Michael (2008), Rose (2013), and Yusuf \& Dansu (2014) adduced to the fact that the way an insurance company manages the claims process is fundamental to its profitability and long-term sustainability and thus, posited that good claim management must be proactively conducted in recognizing and paying legitimate claims; and assessing accurately the reserve associated with each claim.

The core objective of this study is to examine the effectiveness, efficiency and promptness of claims handling process in the Nigerian Insurance Industry. Other objectives include: ascertaining the claims handling activities; investigating the roles of claims management team in designing strategies for fraud detection and prevention; and assessing claims handling procedures in meeting the expectations of various customers.

\section{Research Questions and Hypotheses}

For the purpose of this study, the following relevant research questions were set:

1. Are effective and efficient claims handling activities significant in claims management operations?

2. Does promptness in claims handling process essential for fraud detection and prevention?

3. Of what significant importance are claims handling processes in meeting customers' expectations in the Nigerian Insurance Industry?

To provide answers to the questions highlighted above, the following testable hypothetical statements were considered:

1. $\mathrm{H}_{0}$ : Managing claims effectively and efficiently will no significantly affect operational process in claims management

2. $\mathrm{H}_{\mathrm{o}}$ : Promptness in claims handling processes does not essentially assist in fraud detection and prevention

\section{Conceptual and Empirical Framework}

A claim, according to DiNapoli (2013), is basically a demand presented for the payment of money due for goods that have been delivered or services that have been provided. Vaughan \&Vaughan (2008) define a claim as a notification to an insurance company that payment of an amount is due under the terms of a policy. An insurance claim, therefore, is a demand by a person or an organization seeking to recover from an insurer for a loss that an insurance policy might cover (Brooks, Popow, \& Hoopes, 2005). Michae (2008) opines that insurance claims range from straightforward domestic building and contents claims that are settled within days of notification to complex bodily injury claims that remain open for many years.

However, a claim on the policy is thus demand on the insure to fulfill its part of the promise, committed to while writing the contract with the insured (Krishnan, 2010). A claim is the defining moment in the relationship between an insurer and its customer (Francis \& Butler, 2010). Singh (2012) thus opines that retaining and growing market share and improving customer acquisition and retention rates, insurers are focused on enhancing customers' claims experience.
Similarly, insurers can transform the claims processing by leveraging modern claims systems that are integrated with robust business intelligence, document and content management systems which will enhance claims processing efficiency and effectiveness.

According to Low (2000), efficiency measures relationship between inputs and outputs or how successfully the inputs have been transformed into outputs. Efficiency is said to focus on the input-output relationship, as opposed to output and outcomes; and that high efficiency would be exemplified by the delivery of a large number for given inputs (Scott, Simon, Nick, \& Karina, 2008). Pinprayong and Siengthai (2012) had noted a difference between business efficiency and organizational efficiency; while business efficiency reveals the performance of input and output ratio, organizational efficiency reflects the improvement of internal processes of the organization such as organizational structure, culture and community. Ilona \& Evelina (2013) argued that effectiveness oriented companies are concerned with output, sales, quality, creation of value added, innovation, cost reduction and thus, must measure the degree to which a business achieves its goals or the way outputs interact with the economic and social environment. Capgemini (2011a) opined that highly effective claims practices can be a key contributor to a differentiated customer experience that strengthens customer loyalty and attract new customers, which is especially valuable in a market with little or no growth.

Excellence in claims handling is being a competitive edge for an insurance company, and it is a service that clients greatly value. Similarly, key components that must be in place in order to deliver excellence in insurance claims handling, according to AIRMIC (2009), were noted as: culture and philosophy, communication, people, infrastructure, claims procedures, data management, operations, and monitoring and review. Brooks et al. (2005), more so, suggest some step-by-step claims handling activities to include: acknowledging and assigning the claim, identifying the policy, contacting the insured or the insured's representative, investigating and documenting the claim, determining the cause of loss and the loss amount, and concluding the claim. Meanwhile, claim efficiency and effectiveness, according to Capgemini (2011b), had been noted to be core benefits for claims transformation, which include: claim handling and administration; allocated loss adjustment expense; indemnity exposure; and total cost of ownership.

The Productivity Commission (2002) as cited in Yusuf \& Dansu (2014) suggest a good claim management embraces: proactive in recognizing and paying legitimate claims; assessing accurately the reserve associated with each claim; reporting regularly; minimizing unnecessary costs; avoiding protracted legal disputation; dealing with claimants courteously; and whatever possible, handling claims expeditiously. Michael (2008) stated that the key elements of a modern claim management system that can process all claim types should include a case management component along with the ability to calculate and process complex reoccurring payments. Therefore, to significantly improve claims management and swiftly adapt to changing situations, insurers must make more profound infrastructure changes that align claims processing with corporate objectives for customer service, operational cost and risk management (TIBCO, 2011). Then, to reduce the cost of claims and deliver on a value-added brand promise to customers, insurers must focus on enhancing efficiency and effectiveness in their claims function (Singh, 2012). 


\section{EFFECTIVENESS, EFFICIENCY, AND PROMPTNESS OF CLAIMS HANDLING PROCESS IN THE NIGERIAN INSURANCE INDUSTRY}

Esri (2012) pointed at five steps for optimizing the insurance claims process to involve data organization, analysis and planning, mobility, management, and customer engagement. Singh (2012) postulated that for insurers to achieve higher levels of operational efficiency and better process effectiveness, they must look towards implementing modern claims system or enhancing their existing claims systems, leveraging advanced fraud detection technologies and innovating around self-service through processing. Rose (2013) affirms that the way an insurance company manages the claims process is fundamental to its profit and long-term sustainability. In this regard, six core aspects of predictive insurance claims processing were noted to include: fraud management, recovery optimization, settlement optimization, claims benchmarking, activity optimization, and litigation management.

\section{Claims Fraud Detection and Prevention}

The earlier study of Derrig \& Krauss (1994) proposed that the word 'fraud' is reserved for criminal acts, probable beyond a reasonable doubt, that violate statutes, making the willful act of obtaining money or value for an insurer under false pretense or material misrepresentation of a crime. Kuria \& Morange (2014) recorded fraud as an omission or act intended to make one gain advantage unlawfully or dishonestly in dealings that can be achieved by intentionally concealing, suppressing, misrepresenting or non-disclosure of material fact pertinent to transactions or financial decision; misappropriating assets; and abusing fiduciary responsibility or position of trust. According to Derrig (2002), insurance fraud is seen as criminal act involving obtaining financial gain from insurer or insured using misrepresentation of facts or false pretenses.

The Crime and Fraud Prevention Bureau (2000) as cited in Nicola, Linden, \& Thomas (2006) noted four main types of fraud in motor insurance and their associated levels of occurrence as: completely false claims $(12 \%)$, deliberately misrepresenting the circumstance of the claim $(32 \%)$, inflated loss value $(39 \%)$, claiming from multiple insurers $(3 \%)$, with $14 \%$ being attributable to other types of fraudulent claims. Yusuf (2010) presented four classes of insurance fraud: internal fraud, intermediary fraud, policyholder fraud, and insurer fraud. Viaene \& Dedene (2004) stated that fraud affects all classes of insurance. The most common insurance fraud which falls within the general or non-life insurance market can be categorized into opportunistic fraud (Yusuf \& Babalola, 2009).

\section{Research Method}

The study employed a survey research design. The engagement of survey design was because of its ability to predict behaviour and assist in gathering identical information concerning all cases in a sample (Bordens \& Abott, 2002; Aldridge \& Levine, 2001). Data were collected through the field survey among insurance companies specifically claims department. The main instrument employed in gathering data was structured questionnaire. The structured questionnaire was employed due to its appropriateness to survey research (Babbie, 2005). The questionnaire consisted of two parts (part $A$ and $B$ ). While part A consisted of personal data of respondents, part B contained statement related to variables understudied. The views of respondents with respect to issues under study was assisted via the completion of the questionnaire which was drawn using a Likert-type scaling measurement of 'strongly agree', 'agree', 'undecided', 'disagree' and 'strongly disagree'.

www.journals.cz
Among 49 insurance companies in Nigeria, which comprise 10 composite insurers, 7 life specialist companies and 32 non-life risks underwriting companies (Asinobi \& Ojo, 2014), 33 companies were chosen consisted of 25 general insurance companies and 8 life insurance companies; giving a $67 \%$ of the industry capacity. The sample population thus was drawn from Lagos metropolis. The choice of Lagos, as an empirical ground for research interest, was because it houses the largest number of insurance companies in Nigeria (Nigerian Insurers Association, 2011). A total of 132 copies of the questionnaire were sent out. 4 copies of the questionnaire were provided for claims managers and other staff within the claims department of each surveyed company accompanied by a covering letter. This study employed a judgmental sampling technique because it assists in selecting unit(s) to be observed on the basis of the researchers' knowledge of judgment of the population, its element and aim of the study (Babbie, 2005). To ensure the genuiness of responses, regular telephone calls, electronic mailing, short visits and assistance from other persons were options to enable proper filling and returning of the questionnaire. Thus, collection of questionnaire was done through self-effort and other research assistants. Eventually, among 121 copies retrieved from the various insurance companies, 107 were correctly completed and these were analyzed for the research (that is, a $81 \%$ effective response rate).

On the reliability and validity of the study, a pilot study was conducted. The Cronbach alpha on questionnaire administration is 0.7981 ; which shows that the alpha level is above the required standard 0.70 . On the validity of the research, both construct and content validity were adopted. The construct validity was designed via measures of the variables understudied from well-grounded literatures on other previous studies. The content validity was designed by giving a set of draft questionnaire to few selected top management staff in the claims department and some members of the academia in the field of insurance. These professionals went through the instrument and came up with formidable suggestions which assisted the researchers in presenting the items within the linguistic understanding of the respondents.

\begin{tabular}{|l|l|l|}
\hline \multicolumn{3}{|l|}{ Table 1: Responses to the testing of hypothesis 1 } \\
\hline Alternatives & Responses & Percentage (\%) \\
\hline Strongly Agree & 8 & 7.48 \\
\hline Agree & 21 & 19.63 \\
\hline Undecided & 14 & 13.08 \\
\hline Disagree & 38 & 35.51 \\
\hline Strongly Disagree & 26 & 24.3 \\
\hline Total & 107 & 100 \\
\hline Source: Authors &
\end{tabular}

\begin{tabular}{|l|l|l|l|l|}
\hline Table 2: One-Sample Statistics \\
\hline & $\mathrm{N}$ & Mean & Std. Deviation & Std. Error Mean \\
\hline $\begin{array}{l}\text { Effective and efficient claims } \\
\text { management and operational } \\
\text { process }\end{array}$ & 107 & 2.5047 & 1.26173 & 0.12198 \\
\hline Source: Authors & & & \\
\hline
\end{tabular}

\begin{tabular}{|c|c|c|c|c|c|c|}
\hline \multicolumn{7}{|l|}{ Table 3: One-Sample Test } \\
\hline & \multicolumn{6}{|c|}{ Test Value $=0$} \\
\hline & \multirow[t]{2}{*}{$t$} & \multirow[t]{2}{*}{$\mathrm{df}$} & \multirow[t]{2}{*}{$\begin{array}{l}\text { Sig. } \\
\text { (2-tail) }\end{array}$} & \multirow[t]{2}{*}{$\begin{array}{l}\text { Mean } \\
\text { Difference }\end{array}$} & \multicolumn{2}{|c|}{$\begin{array}{l}95 \% \text { confidence } \\
\text { intervention of } \\
\text { the difference }\end{array}$} \\
\hline & & & & & Lower & Upper \\
\hline $\begin{array}{l}\text { Effective and efficient claims } \\
\text { management and operational } \\
\text { process }\end{array}$ & 20.534 & 106 & 0 & 2.50467 & 2.2628 & 2.7465 \\
\hline Source: Authors & & & & & & \\
\hline
\end{tabular}




\section{EFFECTIVENESS, EFFICIENCY, AND PROMPTNESS OF CLAIMS HANDLING PROCESS IN THE NIGERIAN INSURANCE INDUSTRY}

The result above shows that the calculated value of 20.53 is greater than the $p$-value of 0.000 at $5 \%$ level of significance (i.e. $D_{\text {cal }}=20.53>p=0.000$ ). Therefore, in consonance with the decision rule, the null hypothesis $\left(\mathrm{H}_{0}\right)$ that Managing claims effectively and efficiently will not significantly affect operational process in claims management is rejected (see Table 1 for respondents views). The researchers then conclude that managing claims effectively and efficiently will significantly affect operational process in claims management. This, therefore confirms the earlier studies of Ashturkar (2014), DiNapoli (2013), Dhanushkoti \& Coates (2006), and OECD (2004), who noted that proactive process at claims handling will provide customers with better resolution and reducing the overall cost of their claims, and thus giving service provider(s) stake in claims handling, insurer can obtain more commitment and better performance from them. Capgemin (2011b) concurs that improved claims handling and administration can effectively streamline and accelerate the claims management lifecycle.

\begin{tabular}{|l|l|l|}
\hline \multicolumn{3}{|l|}{ Table 4: Responses to the testing of hypothesis 2 } \\
\hline Alternatives & Responses & Percentage (\%) \\
\hline Strongly Agree & 5 & 4.67 \\
\hline Agree & 17 & 15.89 \\
\hline Undecided & 11 & 10.28 \\
\hline Disagree & 43 & 40.19 \\
\hline Strongly Disagree & 31 & 28.87 \\
\hline Total & 107 & 100 \\
\hline Source: Authors & \multicolumn{2}{|l}{} \\
\hline
\end{tabular}

\begin{tabular}{|l|l|l|l|l|}
\hline \multicolumn{5}{|l|}{ Table 5: One-Sample Statistics } \\
\hline & $\mathrm{N}$ & Mean & Std. Deviation & Std. Error Mean \\
\hline $\begin{array}{l}\text { Effective and efficient claims } \\
\text { management and operational } \\
\text { process }\end{array}$ & 107 & 2.271 & 1.17818 & 0.1139 \\
\hline Source: Authors & & & \\
\hline
\end{tabular}

\begin{tabular}{|l|l|l|l|l|l|l|}
\hline Table 6: One-Sample Test \\
\cline { 2 - 6 } & t & df & $\begin{array}{l}\text { Sig. } \\
\text { (2-tail) }\end{array}$ & $\begin{array}{l}\text { Mean } \\
\text { Difference }\end{array}$ & $\begin{array}{l}95 \% \text { confidence } \\
\text { intervention of } \\
\text { the difference }\end{array}$ \\
\hline \begin{tabular}{ll|l|l|l|} 
Lower \\
Upper
\end{tabular} \\
\hline $\begin{array}{l}\text { Promptness in claims } \\
\text { handling process and fraud } \\
\text { detection and prevention }\end{array}$ & 20.534 & 106 & 0 & 2.27103 & 2.0452 & 2.4968 \\
\hline Source: Authors & & & \\
\hline
\end{tabular}

From the table above, the calculated value of 19.93 is greater than the $p$-value of 0.000 at $5 \%$ level of significance (i.e. $D_{\text {cal }}=19.93>p=0.000$ ). Therefore, in compliance with the decision rule, the null hypothesis $\left(\mathrm{H}_{0}\right)$ that promptness in claims handling process does not essentially assist in fraud detection and prevention is rejected (see Table 4 for respondents' views). The therefore indicates that promptness in claims handling processes does essentially assist in fraud detection and prevention. Again, this result supports the view of Accenture (2013), who noted that a thorough assessment of fraud detection capabilities and the feasibility of an enhanced fraud detection process will help optimize and improve the enterprise's return on investmen in fighting fraud. Also in affirmation of the result is the study of Nicola et al. (2006), who noted that knowledge limitations are likely to preclude the detection of some classes of fraudulent claims such as financial exaggerations.

\section{CONCLUSION}

This study has been able to confirm the effectiveness, efficiency and promptness of claims handling process with the Nigerian insurance industry as a research ground for its empirical assessment. The findings of the study have proven that effective and efficient management of claims can further enhance the operational process in insurance business. Rose (2013) affirms that the way an insurance company manages the claims process is fundamental to its profit and long-term sustainability. Capgemini (2011a) opined that highly effective claims practices can be a key contributor to a differentiated customer experience that strengthens customer loyalty and attract new customers, which is especially valuable in a market with little or no growth.

On recommendation, claims manager should put forward strategic plans to ensuring that insurance claims complaint files are properly kept, monitored and handled for needs that may warrant its usefulness in the future. Secondly, state-ofthe-art training mechanism should be put in place to enhance and improve the working pattern of a claim officer which invariably might affect the organizational efficiency of insurance companies. Claims handling procedures should be promptly managed to avoid deficiency in organization's operational objectives. More so, regulators and other stakeholders within the industry should at regular interval intensify effort to ascertaining the claims handling procedural methods in use by insurance companies in Nigeria; and lastly, Government should ammonize their resources and technical know how with the Nigerian insurance industry in ensuring that insurance claims are well designed to curtail fraudulent claims experienced in the past.

This study suggests that future studies should focus efforts at gathering information from the insuring populace as related to customers' experience of insurance claims in Nigeria. Additionally, the various claims handling modes should be understudied to ascertain their acceptance level among the insurance companies and the use to which they are put. Research efforts could be drawn at designing insurance claims model for addressing the lingering perceived customer image related to insurance fraud in Nigeria. Lastly, future research could also attend to detecting and preventing insurance fraud within the Nigerian insurance industry.

\section{REFERENCES}

Ashturkar, P.B. (2014). Comparative study of effectiveness of claims settlement operations in Indian life insurance companies. International Journal of Advance Research in Computer Science and Management Studies, 2(11),148-155.

Asokere, A.S \& Nwankwo, S.I. (2010). Essential of insurance: A modern approach(1st ed.). Lagos: Fevas Publishing.

Association of Insurance and Risk Managers in Industry and Commerce (2009). Delivery excellence in insurance claims handling: Guide to best practice. London: AIRMIC

Brooks, P.J., Popow, D.J., \& Hoopes, D.L. (2005). Introduction to claims. Pennsylvania: American Institute for Chartered Property Casualty Underwriters.

Capgemini (2011a). Claims transformation: Enhancing brand value by delivery on customer commitments, capturing efficiency gains, and optimizing indemnity expenditures.

Capgemini (2011b). Capturing operational efficiency and sustainable value through claims. Guidewire. Retrieved from http://www.capgemini.com/claims

Crawford (2007). Trends in claims handling: Insurance industry update. Canada: Crawford \& Company Inc.

Derrig, R.A. (2002). Insurance fraud. Journal of Risk and Insurance, 69(3), 271-287

Derrig, R.A., \& Krauss, L. (1994). First steps to fight workers' compensation fraud. Journal of Insurance Regulation, 12, 390-415.

Dhanushkoti, S.,\& Coates, P. (2006, April). Insurance claims management -improving efficiency and effectiveness to reduce cost 
of claims. AIR Cover Story. Retrieved from: http://www.asiainsurancereview.com

DiNapoli, T.P. (2013). Improving the effectiveness of your claims auditing process. Office of the New York State comptroller. Retrieved from http://.www.osc.state.ny.us

Esri (2012, April). GIS for the insurance claims process: five steps for an effective workflow. California: Esri White Paper.

Francis, P., \& Butler, S. (2010). Cutting the cost of insurance claims: taking control of the process. Booz \& Company. Retrieved from http://www.booz.com

IBM (2011). Three ways to improve claims management with business analytics. USA: IBM Corporation.

Ilona, B., and Evelina, S. (2013). Organizational assessment effectiveness vs. efficiency. Social Transformations in Contemporary Society, 1, 45-53.

Khan, M.T., Khan, N.A., Ahmed, S., \& Ali, M. (2012). Connotation of organizational effectiveness and factors affecting it. International Journal of Business and Behavioural Sciences, 2(9), 21-29.

Krishnan, B. (2010). Claims management and claims settlements in life insurance. The Journal of Insurance Institute of India, 36 (Jul-Dec), 49-57.

Kuria, J.T., \& Moronge, M. (2014). Effect of fraud control mechanisms of the growth of insurance companies in Kenya. International Journal of Innovative Social \& Science Education Research, 2(1), 26-39.

Low, J. (2000). The value of creation index. Journal of Intellectual Capital, 1(3), 252-262.

Michael, K. (2008). The increasing importance of claim management to insurers. Claims Vendor Showcase, FINEOS Corporation.

Nicola, J.M, Linden, J.B., \& Thomas, C.O. (2006). How the detection of insurance fraud succeeds and fails. Psychology, Crime \& Law, 12(2), 163-180.

Organization for Economic Co-operation and Development (2004) Guidelines for good practice for insurance claims management. Retrieved from http://www.oecd.org/corporate/ca/corporategovern aceprinciples

Pinprayong, B., \& Siengtai, S. (2012). Restructuring for organizational efficiency in the banking sector in Thailand: a case study of Siam Commercial Bank. Far East Journal of Psychology and Business, 8(2), 29-42.

Productivity Commission (2002). Public liability claims management. Canberra: Research Report.

Productivity Commission (2013). On efficiency and effectiveness: some definitions. Canberra: Staff Research Note.

Rose, S. (2013). Predictive claims processing: transforming the insurance claims life cycle using analytics. SAS White Paper, 1-8.

Scott, A., Simon, B., Nick, H., \& Karina, W. (2008). Assessing multilateral organization effectiveness: Evaluation Study 2008/3, from Danida's Evaluation Department-Development Cooperation, Ministry of Foreign Affairs

Singh, V. (2012). Global trends in non-life insurance: claims. Capgemini.

TIBCO (2011). Dynamic claims processing. USA: TIBCO Software Inc.

Vaughan, E.J., \& Vaughan, T.M. (2008). Fundamental of risk and insurance. USA: John Wiley Sons, Inc.

Viaene, S., \& Dedene, G. (2004). Insurance fraud issues and challenges. The Geneva Papers on Risk and Insurance, 29(2), 313-333.

Yusuf, T.O. (2010). Brokers and the control of postcontractual opportunism in the Nigerian Insurance market. Journal of Financial Crime, 17(2), 223-239.

Yusuf, T.O., \& Babalola, A.R. (2009). Control of insurance fraud in Nigeria: an exploratory study (case study). Journal of Financia Crime, 16(4), 418-435.

Yusuf, T.O., \& Dansu, F.S. (2014). Effect of claims cost on insurers profitability in Nigeria. International Journal of Business and Commerce, 3(10), 1-20.

www.journals.cz
Zheng, W., Yang, B., \& McLean, G. (2010). Linking organizational culture, structure, strategy, and organizational effectiveness: mediating role of knowledge management. Journal of Business Rsearch, 63(7), 763-771. 